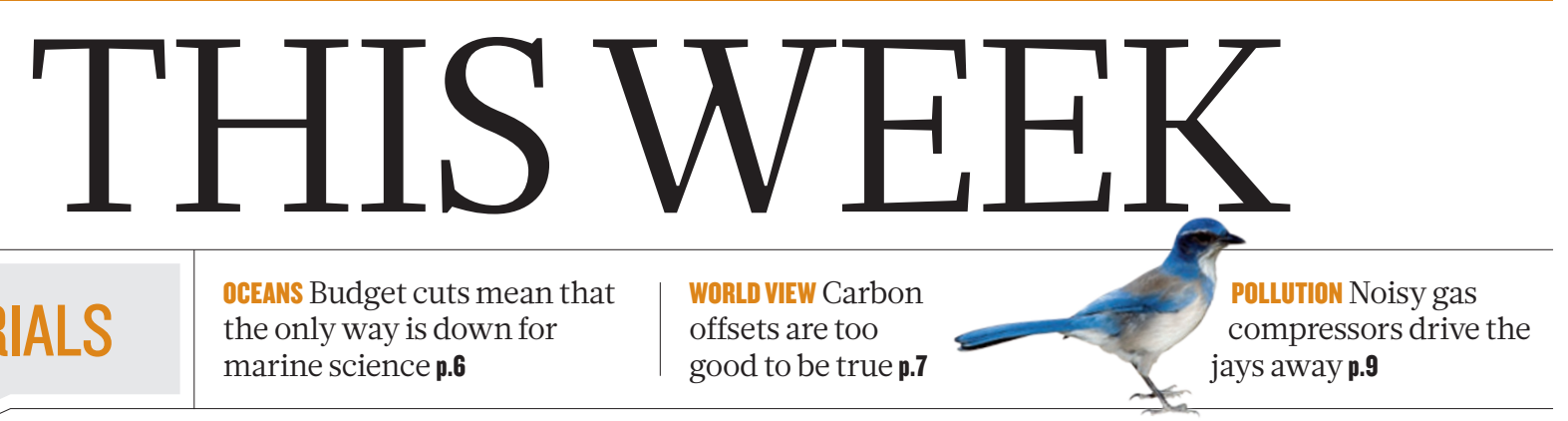

\title{
Bolstering the link
}

\section{Two papers in Nature this week highlight the extent to which human activity is influencing global climate, and underline the need for continued scrutiny of the problem.}

$\mathrm{T}$ The United States gave Old King Coal a bloody nose last week, with proposals to regulate fossil-fuel emissions that would effectively ban new coal-fired power plants unless they come equipped with technology to capture and store carbon dioxide. The impact in the short term may be minimal: protests against plans for individual new coal power stations and the dash for shale gas as an alternative energy source have forced coal back in the energy pecking order. But, with federal inaction on the climate-change question likely to continue, the move by the Environmental Protection Agency is a welcome one. The agency is finally using the power given to it by the Supreme Court in 2007 to treat carbon dioxide as a pollutant. At the same time, the United Kingdom, which likes to think of itself as an international leader on global warming, seems to be weakening its resolve at home. The Conservative-Liberal Democrat coalition has loosened similar plans to restrict greenhouse-gas emissions from gas-powered electricity generation, although rules that effectively force carbon capture on new British coal power stations remain in place. And, given the government's concomitant failure to announce new mandatory carbon reporting for British business, as required by the 2008 Climate Change Act, it is clear that voters in Britain who were told that they were getting the greenest government ever have been misled.

As the politics of global warming swirls, climate science marches on. This week, two papers in Nature underscore what we thought we knew about the problem, as well as offering the kind of surprising result that shows why research must continue apace.

First, as Jeremy Shakun at Harvard University in Cambridge, Massachusetts, and his colleagues show on page 49 , carbon dioxide does drive atmospheric warming. Uncontroversial stuff, perhaps, yet the link continues to be questioned by people who would play down the risks of human greenhouse-gas emissions. The queries re-emerged in 2006, when former US vice-president Al Gore showed a graph of historical carbon dioxide levels and temperature in his movie, An Inconvenient Truth, and was accused of glossing over the relationship between the two. So let there be no confusion now: the new study confirms that, as Earth emerged from the last ice age some 19,000 to 10,000 years ago, rising global temperatures were preceded by increased global carbon dioxide in the atmosphere - a result that emphasizes the role of carbon dioxide in driving global change in the present day. This relationship is a foundation stone of climate science and of policies to regulate greenhouse-gas emissions, and it is solid.

Quelle surprise! the climate sceptics may shout - scientists find proxy data and use a computer model to get the answer they wanted, to seal the conspiracy. Then let the second paper this week show that modern science does anything but offer self-serving results to support existing ideas. For, in a paper published online, Ben Booth and his colleagues at the Met Office Hadley Centre in Exeter, UK, use a different model to question conventional wisdom on how the climate of the North Atlantic Ocean operates (B. B. B. Booth et al. Nature

\section{http://dx.doi.org/10.1038/nature10946; 2012).}

This study looks at the impact of aerosols - such as sulphur dioxide particles ejected by volcanoes and linked to the burning of coal - on sea surface temperatures there. Aerosols that reflect sunlight and can promote brighter cloud formation have been known for some time to affect climate, but the idea has gained appeal in the media during the
"Modern science does anything but offer self-serving results to support existing ideas."

cesses, such as the frequency of Atlantic hurricanes and drought in the Sahel region of Africa in the 1980s, the findings greatly extend the possible reach of human activity on global climate. Moreover, if correct, the study effectively does away with the AMO as it is currently posited, in that the multidecadal oscillation is neither truly oscillatory nor multidecadal.

The implications of this are great, both for study of the climate system and for the impact of policies to control aerosol emissions. It also shows that solid science does not have to be settled science, and that this is no bad thing.

\section{Creative tensions}

\author{
Scientists must find ways to improve academic \\ efficiency if they are to keep their independence.
}

$\mathrm{T}$ True scientific creativity is often presumed to be the preserve of independent investigators operating in an environment with none of the practical or political concerns that dog many other workers. In truth, far from being creative, most scientists spend much of their time worrying about funding, sitting in meetings and dealing with administrative bureaucracy.

But, in many ways, academics do live very sheltered lives by today's standards - how many other careers offer tenure or employment for life? And, frequently, an individual's insistence on working as free from tethers as possible can be taken too far, forcing everyone and everything around them to accommodate their needs. This becomes a waste of time and effort - in other words, of money. In this age of economic austerity, has the concept of absolute academic autonomy become a luxury that the scientific enterprise can no longer afford?

A series of Comment articles this week tackles this thorny issue head-on. On page 27, consultant Thomas Marty describes how, in some 
departments, faculty members insist on each doing their own course planning, choosing times and subjects independently. This forces the administration to revise courses to ensure that the credits assigned to each are consistent, that students have taken the prerequisites the professors require, and that everything is presented in the format that the computer system recognizes, so that students can register online. Although this may sound like part of administrators' responsibilities, the job can be so big that one department Marty worked with had to dedicate two full-time staff members to resolving such conflicts. Yet academics often grumble at the resources their universities devote to administration.

If scientists truly value their autonomy, they must let go of the traditions that cause more harm than good to the research enterprise. According to Paula Stephan, on page 29, these traditions are often tied to counterproductive financial incentives, such as a US government accounting rule that allows universities to use debt from new construction to increase the indirect rate that they add to grants for overhead costs. This encourages universities to constantly expand rather than house researchers in buildings they already own, and creates an idea that bigger is always better. But, in biomedical sciences, bigger labs have not been associated with a substantial increase in output, and the economic downturn means "the building boom is now costing the scientific enterprise by creating excess space that cannot be paid for", says Stephan.

Scientists may bristle at some of the suggestions proposed to improve the efficiency of the research enterprise. Run academic institutions more like private businesses? Increase the power of institute directors and university presidents so they can make more executive decisions without asking for faculty members' input? Place a 'tax' on the use of temporary workers such as graduate students and postdocs, to encourage scientists to hire more permanent staff scientists?

But scientists should think twice about this instinctive, defensive approach. Something that may seem a threat to academic autonomy is often quite the opposite. A standard template for course planning that all faculty members must adhere to, for example, with strict deadlines for each phase, could cut the number of course revisions. This would free staff to deal with other administrative issues, letting the scientists who had been shouldering that burden get back to research and teaching. Similarly, every 16-person committee that meets once every 2 months

"Something that may seem a threat to academic autonomy is often quite the opposite." for 4 hours can amount to as much as 100 labour days per year, when other costs such as preparation time and staff support are taken into account. Although giving leaders more power to make executive decisions without consulting faculty members may seem to threaten academic independence, in this instance giving up decision-making powers allows scientists to spend more time doing creative, independent research.

And if scientists truly value their power and independence, they must lead the discussion over what works in the research enterprise - and what doesn't. If they don't, someone else will make those decisions for them, by imposing even more funding cuts that directly hurt research and teaching. Scientists cannot continue to live by the double standard that Pierre Azoulay recognizes on page 31, applying deep scepticism to scientific data but unquestioning faith to the practice of science itself. They must approach suggestions to improve academic efficiency with an open mind, trying some and noting whether any impinge on their creativity. However, if implemented properly, none of the suggested changes should have any impact on scientists' all-important academic freedom. If we strengthen the system that supports it, science can only thrive.

\section{Into the depths}

\section{Celebrity missions to the deep ocean won't make up for cuts to marine science.}

L ast week, depending on your point of view, film director James Cameron either made history or reached a new low. In descending to the deepest part of the ocean, Cameron became the first human to make a solo visit to the Challenger Deep, nearly 11 kilometres from the surface. He is only the third person ever to make such a dive (see Nature http://doi.org/hsj; 2012).

Cameron's mission mostly failed in its scientific ambition to recover samples. Equipment failure allowed his submersible to bring back just one piece of sediment and no rocks. But his team has pledged to make further dives, and although there may be no large creatures lurking at that depth, the opportunity to analyse the microorganisms likely to be found in the sediment is unprecedented.

Congratulations flooded in from around the world, many from marine scientists. Among those to send good wishes was the UK National Oceanography Centre (NOC).

But a week that started brightly for the field ended less well. Although Cameron was inspiring the next generation of marine scientists on Monday, by Wednesday news was reaching Nature that the NOC was shedding nearly one-quarter of its scientific staff, based at sites in Southampton and Liverpool (see Nature http://doi.org/hsk; 2012).

This is partly a response to Britain's financial woes, which have kept down or cut budgets at the country's research funding councils in recent years. But the centre's problems have been exacerbated by the stance of the UK Natural Environment Research Council (NERC) — which provides most of the NOC's funding and has decided to "gradually shift the balance of science funding from long-term survey, monitoring and infrastructure such as ships towards front-line, competitively awarded, strategic environmental research", it said in a statement.

The upshot is that 35 posts are to be lost in the NOC's science section, as the centre attempts to make savings of $£ 3.5$ million (US $\$ 5.6$ million) a year on its $\mathfrak{£} 45$-million annual budget.

Ocean researchers around the world have been devastated by the news of the cutbacks, which jeopardize a number of international collaborations in areas such as climate and ocean modelling.

NERC insists that the NOC will still be a major player in the field, albeit "with a somewhat leaner, but even more highly competitive scientific team". But researchers fear that this focus will threaten projects that gestate slowly, which have until now been highly valued.

In the United States, too, researchers have reason to fret. Budget negotiations can be tortuous, with nothing set in stone until the final vote, but there is growing concern about the future of the National Undersea Research Program (NURP). The programme, run by the US National Oceanic and Atmospheric Administration (NOAA), hosts much of the country's research fleet of scientific submersibles. Other NOAA programmes are also under scrutiny.

When the costs of high-profile glamour projects such as manned space flight draw criticism, supporters often say that their publicengagement value offsets mission costs. With Cameron's dive, science got a freebie. No government funds that could have gone to austerityhit research labs were used: this was one man doing what he wanted with his own money. Others with similar means are set to follow Cameron into the deep, and wealthy individuals are likely to reach space under their own steam and on their own terms in the near future.

But will science be well placed to exploit the massive appeal of Cameron's dive and the new attention that will be given to the ocean depths? Scientists have sent unmanned vehicles to the Challenger Deep between the manned mission in 1960 and last week's visit. Those $\rightarrow$ NATURE.COM To comment online, click on Editorials at: go.nature.com/xhunqv trips were made with kit that relies on the skill and dedication of scientists working for programmes such as NURP and the NOC. While Cameron celebrates, ocean science slips a little further out of reach for everyone else. 